\title{
Integration of Problem Based Learning at Kathmandu Medical College
}

\author{
Lama PY', Koirala P², Bhattarai B ${ }^{3}$, Suwal G ${ }^{4}$, Deshar $\mathbf{S}^{5}$ \\ ${ }^{1}$ Pratik Yonjan Lama, ${ }^{2}$ Pramesh Koirala, ${ }^{3}$ Binita Bhattarai, ${ }^{4}$ Gopal Suwal, ${ }^{5}$ Sunkeshari Deshar, Medical Offi- \\ cers, Medical Education Department, Kathmandu Medical College Teaching Hospital
}

\section{Abstract}

Problem based learning as an alternative method of teaching had its initiation in Nepal at the Institute of Medicine, Maharajgunj in 1978. From 2011, problem based learning has been introduced into the curriculum of all the medical colleges under Kathmandu University. However, successful implementation into the curriculum is still in the process of development. The objective of the article is to have a profound view on the students' perspective towards the integration of Problem Based Learning in MBBS curriculum and the possible action plans for the effective implementation. A questionnaire survey was done in which a total of 114 out of 150 students of Kathmandu Medical College, MBBS second year participated. The results obtained suggested that problem based learning helps students remember and understand better than traditional lectures, increases integrative ability, self directed learning, sharpens analytic skills and develops group skills. Students believe that the role of facilitator in problem based learning in Kathmandu Medical College has been to motivate students, evaluate them and make a real effort in understanding their difficulties. However there are not enough sessions to cover the system blocks, aims and objectives in the course curriculum are not clear, topics covered in the sessions of problem based learning should be covered in the lecture hours also and meeting among the facilitators with an inclusion of a student representative has to be made. However, in the view of current scenario of student centered teaching, problem based learning has made a positive impact in students' learning experience.

Key words: Problem based learning, self-directed learning, student centered teaching

\section{INTRODUCTION}

roblem based learning (PBL) is a student centered, self-directed, integrated and contextual mode of learning. It was introduced by Barrows ${ }^{1}$ in the McMaster University, Toronto, Canada in the mid 1960's.

Medical education in Nepal took first step from Tribhuvan University (TU) Institute of Medicine (IOM), Maharajgunj in 1978 with the MBBS programme ${ }^{2}$. Right from inception, the MBBS programme intended to incorporate the philosophy of community-based learning, integrated teaching and problem-based learning. However

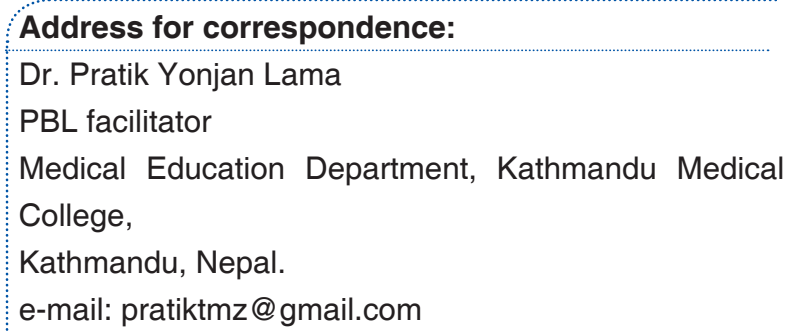

integration of PBL into the curriculum was not without obstacles. Several factors interplayed in delaying implementation of PBL which include faculty's inadequate firsthand experience in the innovative methods, lack of co-ordination and cooperation with teachers and clinicians in PBL compared to teaching in traditional way. After conducting many workshops on PBL, discussions with faculty teachers and with leadership commitment from institutional head, PBL was finally introduced into the basic science curriculum of the MBBS programme and the process unexpectedly took a long time.

From the very first batch of students, PBL was adopted as an integral part of the curriculum in Kathmandu University School of Medical Sciences (KUSMS) since $2001^{3}$. KUSMS had first input of some non-medical experts from Harvard University for two years. Then it was guided till 2008 by Prof. KY Sohn who had done his graduation and post graduation from Mc Master University. 
Table 1: PBL case library for first year MBBS

students, 2013

\section{SN Cases of Different systems}

\section{(A) BASIC CONCEPTS, GENETICS AND IMMUNOLOGY}

1. A road to nowhere (Cannabis abuse)

2. Maya's troubled finger (Cellulitis)

3. A fun loving child (Down's syndrome)

4. A day to remember (Anaphylaxis)

(B) ANS*, MUSCULOSKELETAL AND INTEGUMENTARY

1. A disturbed wife (Organophosphorous poisoning)

2. Swollen knee (Osteomyelitis)

3. A social stigma ( Leprosy)

\section{(C) HAEMATOLOGY}

1. Fever with chills (Malaria)

2. A big tragedy to a small child $\left(\mathrm{ALL}^{\dagger}\right)$

(D) CARDIOVASCULAR SYSTEM

1. Urban tycoon $\left(\mathrm{MI}^{\ddagger}\right)$

2. Fever with fleeting joint pain $\left(\mathrm{RF}^{\S}\right)$

(E) RESPIRATORY SYSTEM

1. Into the thin air (High altitude sickness)

2. Shortness of breath (COPD)

3. A thief's story (Tuberculosis)

*Autonomic Nervous System; ${ }^{\dagger}$ Acute Lymphoblastic Leukemia; ‡Myocardial Infarction; ${ }^{\circledR}$ Rheumatic Fever.

Under mutual co-operation with Linkoping University ${ }^{4}$ in Sweden, Kathmandu Medical College (KMC) introduced $\mathrm{PBL}$ in basic sciences in 2006. With the guidance from the Medical Education Department of KMC and the facilitators from Linkoping University, workshops were conducted to orient the faculty teachers on PBL. The student exchange programme was also a boost for implementation of PBL. As early as 2008 were PBL themes introduced to students, one in each of the first and second years. But it was after the revision of syllabus by Kathmandu University in 2011 that PBL was imposed upon all the affiliated medical colleges under Kathmandu University. With little of orientation programme from KUSMS and in constraints of time, PBL had to be integrated into KMC curriculum. To stay in track with the curriculum a team of PBL coordinators and medical officers was formed under the guidance of Department of Medical Education. Over a year, PBL cases were collected from various sources like KU, IOM, BPKIHS, Linkoping University, revised and new cases prepared to meet the objectives given in the KU course syllabus. Currently more than $20 \mathrm{PBL}$ themes, categorized as per the human body systems are conducted over two years of time.

At present, 150 students of each year are divided into 12 groups of 12 to 13 students each. Medical officers and faculty teachers of the different basic science departments and community medicine department act as a facilitators. Four sessions are conducted for each PBL cases. A guide book for the whole year has also been prepared to help facilitators guide students in all the PBL sessions.

To further motivate the students, provision for assessment on the grounds of attendance, punctuality, discipline, team works and leadership has also been made. The assessment is done by individual PBL facilitators at the conclusion of each $\mathrm{PBL}$ session and the marks from the assessment are added up in the internal examination.

Table 2: PBL case library for second year MBBS students, 2013

\section{SN TOPIC \\ (A) GASTROINTESTINAL AND HEPATOBILIARY SYSTEM}

1. Acid peptic disease

2. A pale alcoholic (Obstructive jaundice)

\section{(B) RENAL SYSTEM}

1. Nephrotic syndrome

2. Big shock to family (Renal tumour)

(C) ENDOCRINE SYSTEM

1. Sugar in adult (Diabetes mellitus)

2. Swelling in the neck (Thyrotoxicosis)

(D) REPRODUCTIVE SYSTEM

1. A sudden agony $\left(\mathrm{HIV}^{*}\right)$

2. A shared problem (infertility)

(E) CENTRAL NERVOUS SYSTEM

1. Meningitis

2. Parkinsonism

3. Cerebrovascular accident

*Human Immunodeficiency Virus 


\section{METHODS}

In order to find the effectiveness of PBL, to make new planning and overcome the challenges, a toolkit consisting of 33 statements was prepared.

The statements were utilized to evaluate and assess under three specific headings:

- Educational Strategy and Information (PBL and Traditional Teaching, Efficacy of the PBL course) 14 statements.

- Facilitators role (including teaching effectiveness/ quality \& methods) - 8 statements

- Student characteristics (Generic skills, Independence performance \& preference/attitude, Group discussion/interaction) - 11 statements

With the toolkit prepared, a questionnaire survey was done. A written questionnaire was distributed to all the students of second year MBBS attending the concluding session of the case "A pale alcoholic" in the gastrointestinal block. A total of 114 out of 150 MBBS second year students, who had undergone PBL sessions in the first year, responded to the statements with agreement, don't know and disagreement. Apart from the questionnaire the students also gave their suggestions in the feedback section.

All the answered questionnaires were collected by department of PBL and the data collected were entered into Microsoft Windows Excel. Analysis was performed using Statistical Package for Social Sciences (SPSS) Version 17. Results obtained were discussed among the faculty members in the basic science and clinical departments of Kathmandu Medical College through a Microsoft power-point presentation. From the discussion in the presentation, faculty's opinion, suggestions and comments regarding their views in implementation and progress of PBL were collected.

\section{RESULTS}

After analysis of the responses given by the students and formal discussion with faculty teachers, a concrete opinion of the students towards PBL and probable action plans were rectified. Overall the result of the survey was encouraging.

Ninety seven (85\%) students felt that the facilitators of this course motivate students to do their best work. As many as $84(74 \%)$ admire the facilitators giving helpful feedback on how we are going. Around 98(86\%) students preferred if the facilitators intervened where appropriate.

In order to improve facilitation skill, as many as 94 (83\%) students recommend the facilitators to be prepared with background information about the topic. Around 91 (80\%) students believe that the mini lectures can be provided by facilitators during PBL and 98 (86\%) say they need the syllabus covered in PBL to be covered in the lecture hours, $82(72 \%)$ students believe that they need the assessment after each session of PBL. To increase the efficacy of PBL session, meetings among the facilitators with an inclusion of a student representative have to be made in the future.

In feedback section, eight students responded with remarks like "There should be PBL everyday"; "PBL methods should be uniform"; "Medical officers and Post-graduate trainee from the Community Medicine Department can better facilitate the students in PBL".

After formal discussion with the faculty teachers of both clinical sciences and basic sciences and sharing the

Table 3: Students' opinion on impact of PBL $(n=114)$

\begin{tabular}{|c|c|c|c|}
\hline Statement & $\begin{array}{c}\text { Agree, } \\
\text { Number (\%) }\end{array}$ & $\begin{array}{l}\text { Do not know, } \\
\text { Number (\%) }\end{array}$ & $\begin{array}{r}\text { Disagree } \\
\text { Number }(\%\end{array}$ \\
\hline $\begin{array}{l}\text { ig helps remember and understand } \\
\text { ures }\end{array}$ & $105(92.1 \%)$ & $6(5.3 \%)$ & $3(2.6 \%)$ \\
\hline n work & $108(94.7 \%)$ & $5(4.4 \%)$ & $1(0.9 \%)$ \\
\hline n skills & 87 (74.7\%) & 19 (16.5\%) & $10(8.8 \%)$ \\
\hline & 92 (80.7\%) & $14(12.3 \%)$ & $8(7 \%)$ \\
\hline emic interests & 97 (85.1\%) & $9(7.9 \%)$ & $8(7 \%)$ \\
\hline
\end{tabular}


Table 4: Students' opinion on medical education and PBL $(n=114)$

\begin{tabular}{|c|c|c|c|}
\hline Statement & $\begin{array}{c}\text { Agree } \\
\text { Number (\%) }\end{array}$ & $\begin{array}{l}\text { Do not know } \\
\text { Number (\%) }\end{array}$ & $\begin{array}{c}\text { Disagree } \\
\text { Number (\%) }\end{array}$ \\
\hline $\begin{array}{l}\text { 1. Medical education like medical practice should reflect local } \\
\text { needs }\end{array}$ & $107(93.9 \%)$ & $6(5.3 \%)$ & $1(0.8 \%)$ \\
\hline $\begin{array}{l}\text { 2. Normal must be taught to the students before teaching the } \\
\text { abnormal }\end{array}$ & $102(89.5 \%)$ & $10(8.8 \%)$ & $2(1.7 \%)$ \\
\hline $\begin{array}{l}\text { 3. More the clinical correlation by } \mathrm{PBL} \text {, greater will be the } \\
\text { understanding of pre-clinical sciences }\end{array}$ & $108(94.7 \%)$ & $4(3.5 \%)$ & $2(1.8 \%)$ \\
\hline $\begin{array}{l}\text { 4. Pre-clinical teaching becomes more realistic when it is done } \\
\text { along with the clinical experience }\end{array}$ & $103(90.35 \%)$ & $10(8.8 \%)$ & $1(0.9 \%)$ \\
\hline $\begin{array}{l}\text { 5. PBL at KMC has tried to integrate many topics from different } \\
\text { basic science subjects }\end{array}$ & $97(85.1 \%)$ & $11(9.7 \%)$ & $6(5.2 \%)$ \\
\hline $\begin{array}{l}\text { 6. The aims and objectives in the course curriculum are made } \\
\text { very clear }\end{array}$ & $57(50 \%)$ & $20(17.5 \%)$ & 37 (32.5\%) \\
\hline 7. There are enough PBL sessions to cover the system block & $23(20.1 \%)$ & $24(21.1 \%)$ & $67(58.8 \%)$ \\
\hline
\end{tabular}

responses from students in the questionnaire, some action plans were proposed. A separate department of PBL has to be formed and only the faculty members of the PBL department should be involved in the process of PBL. Practical hours and lecture hours should be reduced and more $\mathrm{PBL}$ sessions have to be incorporated into the curriculum. To further motivate faculty teachers they felt the need of raise in incentives. Other concerns were availability of resources and involvement of faculty teachers from clinical sciences.

\section{DISCUSSION}

The results obtained clearly showed that PBL has helped students get motivated and has a positive impact in their learning experience. The results are very close to what was observed in IOM in $2000^{2}$. However, there is room for improvement. Though students are being motivated to learn, how much the faculty teachers are motivated and dedicated in conducting PBL classes is a big question mark. Lack of experience in PBL also has its role in this. So, meetings should be conducted with the faculty teachers and their opinions shared regularly before conducting the PBL sessions. More workshops on PBL training should be conducted so that all the faculty teachers are oriented in PBL. After completion of each PBL session wrap up session should also be conducted to get regular feedbacks from students.
The results from the questionnaire survey were based only on students' perception. Hence effectiveness of PBL over traditional teaching cannot be truly determined. Such an assessment could have been done with an experimental study with a control group with traditionally taught students and case group with students who had undergone $\mathrm{PBL}$ followed by an evaluation for both the groups on same terms. But, dividing students for control and case group in the same institution also has its limitations.

In the current curriculum both PBL and the traditional teaching is going side by side. So, true effectiveness of one over the other cannot be determined. Though, it can be accepted that PBL is an alternative and innovative method of learning and teaching.

\section{CONCLUSION}

Over the two years, after integration of $\mathrm{PBL}$ into curriculum, KMC has definitely progressed in systematically conducting the PBL. With time PBL has been accepted by the faculty and integrated into the curriculum. PBL has provided a better environment for development of MBBS students as they take their first steps into medical education. In the view of current scenario of student centered teaching, PBL has made a positive impact in student's learning experience, has motivated them and helped them to be a more capable leader, team member and a better student. 
The current KMC curriculum incorporates principles of both traditional teaching and problem based learning as demanded by the $\mathrm{KU}$ syllabus. Undoubtedly it has benefits; however the current system of teaching has cracks $^{6}$ in it. The objectives of the curriculum, the teaching methods of all the affiliated medical colleges and the assessment by the individual colleges and the Kathmandu University are not aligned ${ }^{8}$ as much as it should be. So, with objectives and the evaluation methodology that are still in the phase of traditional practice, progression into totally PBL curriculum in both basic sciences and clinical sciences is still far ahead.

\section{ACKNOWLEDGEMENT}

We are grateful to Prof. Hemang Dixit and Dr. Binita Pradhan (Department of Medical Education, KMC) for encouraging us with this study. We would also like to express sincere thanks to all the faculty teachers of the basic sciences, Community Medicine Department and the clinical sciences for their active support and contribution for implementation of PBL in KMC.

\section{REFERENCES}

1. Barrows HS. A Taxonomy of Problem Based Learning Methods. Medical education. 1986; 20: 481-6.

2. Pant DS. Experiences from the Institute of Medicine, Tribhuvan University on introducing Problem Based Learning (PBL) in an organ system based integrated curriculum. J. Nep Med Assoc. 2000 April-June;39:232-9.

3. Mansur DI, Kayastha SR, Makaju R, Dongol M. Problem based learning in Medical Education. Kathmandu Univ Med J. 2012;10(4):78-82.

4. Pradhan B, Ranjit E, Ghimire MR, Dixit $H$. History of Problem Based Learning in Nepal and experiences at Kathmandu Medical College. Journal of Kathmandu Medical College. 2012 Sep;1(1):37-44.

medicine and bachelor of surgery. Revised edition 2011.

6. Azer SA, Mclean M, Onishi H, Tagawa M. Cracks in problem-based learning: What is your action plan. Medical teacher. 2013 Dec.

7. Butler R, Inman D, and Lobb D. Problem-based learning and the medical school; another case of the emperor's new clothes? Adv Physiol Educ. 2005 Dec;29(4):194-6.

8. Biggs J. Aligning Teaching and Assessment to Curriculum Objectives. LTSN Generic Centre. 2003.

9. Harden RM, Crosby JR. AMEE Education Guide No 20. The good teacher is more than a lecturer: the twelve roles of the teacher. Medical teacher. 2000; 22(4): 334-47.

5. Kathmandu University. Curriculum for bachelor of 